\title{
NEUROPHYSIOLOGY AND SIGNALING PATHWAYS
}

\author{
Ivana Stankovic Matic ${ }^{1}$, Vladimir Zivkovic ${ }^{2}$ \\ ${ }^{1}$ University of Kragujevac, Kragujevac, Serbia, Faculty of Medical Sciences \\ 2Institute of Radiology, Military Medical Academy of University of Defence, Belgrade, Serbia
}

\section{NEUROFIZIOLOGIJA I SIGNALNI PUTEVI}

\author{
Ivana Stanković Matić1, Vladmir Živković2 \\ IUniverzitet u Kragujevcu, Srbija, Fakultet medicinskih nauka, Kragujevac \\ 2 Institut za radiologiju, Vojnomedicinska akademija Univerziteta odbrane, Beograd
}

\begin{abstract}
An important starting step in understanding the neurobiology of memory lies in identifying locations of physical and chemical changes that follow cognition. As Hebb indicated, and as shown on computer models, memory is a consequence of subtle alterations in synapses. Synaptic response is not invariant, but can be altered by a variety of homo and hetero-synaptic factors, such as modulatory neurotransmitters. This approach helps branching the search for the very physiology of memory - synaptic modification, but rises many questions about modulation of synaptic transmission. The synaptic modification associated with memory capacity can be too small and too widely distributed in the brain, which consequently makes observation and experimental studies more difficult.

Explorations of nervous system in invertebrates proved Hebb's theory that memories can be formed by synaptic alterations, therefore it's also possible to identify some molecular mechanism that leads to this synaptic plasticity. Although non-synaptic changes may also occur in studies of certain types of memory, there is little doubt that the synapse is an important location of information storage.

Hippocampus is confirmed in declarative memory (explicit type, relational type of memory). The focus of this work is on biological perspective that propose memory systems with different functions and distinct anatomical organization. Interdisciplinary approach is of great importance for complete understanding of the very physical basis of memory.
\end{abstract}

Key words: memory, learning, neurobiology, signal transduction, neuronal plasticity.

\section{SYNAPTIC PLASTICITY IN THE HIPPOCAMPUS AND NEOCORTEX}

Narrative memory is somewhat ethereal. Information is easily remembered, but also easily erased from the memory, and they can be results of small synaptic modifications widely distributed in the brain (1). These characteristics make this type of memory very interesting for studying at the synaptic level. Nevertheless, procedural memory has characteristics which make it perhaps even more approachable for studying. Despite the fact that this type of memory is especially strong, it has been proven that it can be formed along simple reflex pathways which connect a sensory stimulus with a movement $(1,2)$.

\section{SA $\boldsymbol{A}$ ETAK}

Važan početni korak u razumevanju neurobiologije pamćenja jeste identifikacija mesta fizičkih i hemijskih procesa u mozgu koji prate ovu kognitivnu funkciju. Hebova teorija, kao i istraživanja na kompjuterskim modelima, pokazali su da je pamćenje posledica suptilnih promena u moždanim sinapsama. Jačina sinaptičkog odgovora nije nepromenljiva, već može da zavisi od različitih homosinaptičkih $i$ heterosinaptičkih faktora, poput onih vezanih za modulatorne neurotransmitere. Ovakav pristup zahteva nova istraživanja fiziologije pamćenja, ali i otvara mnoga pitanja koja se odnose na modulaciju sinaptičke transmisije. Sinaptička modifikacija koja prati memorijske kapacitete može biti premala i previše difuzno distribuirana u samom mozgu, što posledično otežava proučavanje i eksperimentalne studije.

Istraživanja na beskičmenjacima potvrdila su Hebovu teoriju, prema kojoj se pamćenje može formirati sinaptičkim alteracijama, pri čemu je moguće identifikovati i molekularne mehanizme koji dovode do ovakve sinaptičke plastičnosti. Iako se mogu javiti $i$ nesinaptičke promene, tokom istraživanja određenih tipova pamćenja rezultati mnogih studija ukazuju na to da sinapsa predstavlja mesto važno za skladištenju informacija.

Hipokampus ima ključnu ulogu u nastanku deklarativnog tipa memorije (relacioni tip, eksplicitni tip memorije). Fokus rada je u prezentaciji biološke perspektive, koja predlaže povezanost memorijskih sistema s raznovrsnim funkcijama $i$ pratećom anatomskom organizacijom mozga. Potpuno razumevanje same fizičke osnove pamćenja upućuje na interdisciplinarni pristup.

Ključne reči: pamćenje, učenje, neurobiologija, prenos signala, neuralna plastičnost.

Procedural learning involves a motor response in reaction to a sensory stimulus (input). This can be divided into two categories: as non-associative learning (habituation and sensitization) and associative learning (classical and instrumental conditioning).

Narrative memory, for instance, the type of memory you would rely on when you want to pass the next exam, includes the neocortex and structures in the medial temporal lobe, including the hippocampus (3). In 1973, Timothy Bliss and Terje Lomo, working together in Norway, made a significant discovery regarding the hippocampus $(4,5)$. Namely, they found that brief, highfrequency electrical stimuli on the excitatory path to the hippocampus produce long-term increase, which reduces 
synaptic resistance by stimulating the synapse (6). This effect is known as long-term potentiation (LTP). Longterm depression (LTD) in the hippocampus has been also described recently. LTP and LTD are considered by many scientists to be important processes of narrative memory formation $(6,7)$. For that reason, a more detailed explanation of LTD and LTP in the hippocampus will be given in this paper (8).

\section{ANATOMY OF THE HIPPOCAMPUS}

The hippocampus consists of two thin interlocking layers of neurons (8). One layer is called gyrus dentatus, and the other Ammon's horn $(8,9)$. Ammon's horn contains four parts, of which only two are of special interest to us: Cornu Ammonis 3 and Cornu Ammonis 1. An important input to the hippocampus is the entorhinal cortex (9). The entorhinal cortex sends information to the hippocampus via the performant path. Axons of the performant path synapse with neurons of the dentate gyrus. The axons from the dentate gyrus (known as the mossy fiber) synapse with cells in the CA3 area of the hippocampus $(9,10)$. The CA3 cells of the hippocampus give an axon that branches after leaving the cell. One branch leaves the hippocampus via the fornix (10). The second branch, called Schaffer collateral, forms a synapse with neurons in the CA1 area of the hippocampus (11). Because of its simple architecture and organization, the hippocampus is an ideal site to study synaptic transmissions in the human brain (12). In the late 1960s, it was discovered that the hippocampus can be isolated from the brain (of experimental animals) and sliced into layers; the slices can be preserved alive in vitro for many hours. In this, so called a brain slice preparation, fibers can be stimulated by electric impulses and synaptic responses can be recorded. This preparation has helped and made it easier to study LTP and LTD $(12,13)$.

\section{MECHANISM OF LTP IN THE CA1 AREA}

Glutamate receptors are mediators of excitatory synaptic transmission in the hippocampus. Neurons in the CA1 area contain postsynaptic N-Methyl-D-aspartate receptors (13). These glutamate receptors initiate the flow of $\mathrm{Ca}^{2+}$ ions, but only if it comes to binding glutamate and when the postsynaptic membrane is depolarized enough to remove $\mathrm{Mg}^{2+}$ which block the cannels $(13,14)$. Furthermore, the inflow of $\mathrm{Ca}^{2+}$ ions through NMDA receptors signalizes specifically when both presynaptic and postsynaptic elements are simultaneously active (15). Considering these facts, one can perceive a relation which indicates that an increase in postsynaptic $\mathrm{Ca}^{2+}$ ions is important for the induction of LTP. For instance, the LTP induction is prevented if the NMDA receptors are pharmacologically inhibited; or the increase of postsynaptic $\mathrm{Ca}^{2+}$ ions is prevented if a $\mathrm{Ca}^{2+}$ chelator is injected into the postsynaptic neuron $(15,16)$. The increase of $\mathrm{Ca}^{2+}$ ions activates two protein kinases: protein kinase $\mathrm{C}(\mathrm{PKC})$ and calcium/calmodulin-dependent protein kinase II (CaMKII). It has been also shown that inhibition of any of the two kinases blocks the induction of LTP (16). Following the increase in postsynaptic $\mathrm{Ca}^{2+}$ ions and the activation of the kinases, the molecular trail leads us to a situation where an activated synapse becomes more difficult to follow (17). Current studies suggest that this trail branches into two possible paths: one would go in the direction of an increased effectiveness of existing $\alpha$ amino-3-hydroxy-5-methyl-4-isoxazolepropionic acid receptors (AMPA) due to phosphorylation (AMPA receptors phosphorylation, either by PKC or by CaMKII, causes a change in a protein that increases ion regulation of the channels); the other path leads to insertion of completely new AMPA receptors into the postsynaptic membrane (in response to the activation by CaMKII, capillary membrane fuses with postsynaptic membrane, which brings new AMPA receptors into the membrane) $(17,18)$. Furthermore, facts reveal that synaptic structures are changed by LTP (18). Basically, postsynaptic dendrites grow and form new synaptic contacts with axons. A single axon can make multiple synaptic connections with the same postsynaptic neuron, which is not a common pattern in the CA1 area (19). This rapid development of synapses increases not only the response of the postsynaptic surface, but it also increases the possibility of the presynaptic glutamate release triggered by an action potential in the axon (20).

\section{MECHANISMS OF LTD IN THE CA1 AREA}

The question that is imposed is whether hippocampal responses could be modified in both directions. It is known that if the intracellular space of the cell is changed, two changes occur. They respond stronger to the new location and weaker to the old. Similar changes were also observed in the cerebral cortex. Experiments on neural circuits suggest that intracellular changes in neurons, that are widely distributed and that store intimation cause synaptic plasticity and synaptic modification (21). From this perspective, memories are coded as specific patterns of synaptic modifications, where some synapses grow stronger, and others, on the contrary, become weaker (21, 22).

Memory is explained by Hebb's theory that states that a synapse becomes stronger, more excited, when its activity correlates with a strong activation of the postsynaptic neuron by other joint inputs. An extension of Hebb's theory is developed in the direction of bidirectional regulation of synaptic strength, so called $B C M$ theory (named after its authors) (23). According to this theory, synapses that are active when the postsynaptic 
cell is only partially depolarized will induce LTD instead of LTP. Surprisingly, LTD is, just like LTP, induced by the influx of $\mathrm{Ca}^{2+}$ ions through NMDA receptors at the postsynaptic level. The question that is imposed is how it is possible that the same signal $\left(\mathrm{Ca}^{2+}\right.$ ions through NMDA receptors) induce both LTD and LTP. The crucial answer lies in the level of NMDA receptors activation. When the postsynaptic neuron is only weakly depolarized, the partial blocking of the NMDA receptors by $\mathrm{Mg}^{2+}$ ions stops almost all $\mathrm{Ca}^{2+}$ ions at the postsynaptic level $(23,24)$. On the other hand, when the postsynaptic neuron is strongly depolarized, the blocking $\mathrm{Mg}^{2+}$ ions are completely removed and $\mathrm{Ca}^{2+}$ ions can flow into the postsynaptic neuron. These different types of responses of $\mathrm{Ca}^{2+}$ ions selectively activate different types of enzymes. Instead of kinases, which are activated by a high concentration of $\mathrm{Ca}^{2+}$ ions, a moderate and prolonged elevation in $\left[\mathrm{Ca}^{2+}\right]$ activates a protein phosphatase, so LTP puts phosphate groups on, while LTD takes them off. Furthermore, the induction of hippocampal LTD can be associated with the internalization of AMPA receptors at the synapse (24). In conclusion, everything testifies to the fact that LTP and LTD are a bidirectional and symmetrical regulation of postsynaptic AMPA receptors $(24,25)$.

\section{LTP, LTD AND MEMORY}

LTP and LTD have caused a lot of interest since theoretical works have shown that the mechanisms of synaptic plasticity can contribute to the formation of narrative memories (25). But these forms of plasticity have to be demonstrated at the level of the neocortex, as well, because the neocortex is considered a site of longterm narrative memory.

Fortunately, recent studies indicate that NMDA receptor-dependent synaptic plasticity, which exists in the hippocampus, also exists in the neocortex (26). It appears that synaptic plasticity along the entire cerebral cortex may be regulated by the same rules and the same mechanisms. But what is the evidence that links LTP and LTD with memory? Until now, all that has been proved is a possible neural basis for the existence of memory if the brain is electrically stimulated. The most useful approach was to test whether the molecules involved in the formation of LTD and LTP have any connections with learning and memory (27).

Testing special memory in rats, so called Morris water maze, was a logical choice because it is known that the performance that is expected here depends on the hippocampus (28). In this test, a rat is placed in a pool filled with cloudy water. Just below the surface of water, there is a small platform in one location in the pool, which allows the rat to escape. A naïve rat, thrown in the water, will swim around until it runs into the platform and climbs onto it $(28,29)$. Normal rats will learn quickly where the platform is located and when subsequently placed in the water, they will swim right to it. Moreover, once they learn what to search for, rats thrown in a new emulsion will learn the task much faster. However, rats with bilateral damage of the hippocampus cannot figure out the game or remember the location of the platform. Studies on LTP and LTD in the hippocampus point out NMDA receptor as the key molecule in the synaptic modification (30). In the 1980 s, in order to test a possible role of hippocampal NMDA receptor in leaning inside the maze, psychologist Richard Morris (creator of the maze) from the University of Edinburgh and his colleagues injected an NMDA receptor blocker into hippocampus of those rats who had been trained in the maze. These rats were subsequently unable to lean either the rules of the game or the location of the platform. This finding strengthens the evidence that supports the idea that NMDA receptor dependent processes have the key role in memory.

After 1987, Susumu Tonegawa at the MIT introduced a revolutionary new approach to the molecular basis of learning and memory. He recognized that molecules and behavior could be connected if an attempt would be made to manipulate with genes of experimental animals. This approach had already been realized with success in organisms such as a fruit fly, but not in mammals. In his first experiment, Susumu Tonegawa, Alcino Silva and their colleagues deleted ('knocked out') the gene for a subunit (alpha) of the CaMKII molecule and found a parallel deficit in hippocampal LTP and memory (31). Since then, many genes of test subjects have been manipulated in order to confirm the role of LTP and LTD mechanisms in learning $(31,32)$. Despite the great power of the genetic approach, there are some serious limitations, as well. For instance, the loss of a function, such as LTP or ability to learn, can be secondary consequences of developmental abnormalities caused by growing up without a certain protein. Furthermore, since all cells, where it is normally expressed, lack the protein, it can be quite difficult to pinpoint and stress where and how the molecule contributes to learning. For these reasons, researchers must find ways to limit their manipulations on the genes to a specific location and specific time (32). In an interesting example of such an approach, Tonegawa, Joe Tsien and others succeeded in limiting deletion of the genes for NMDA receptors in the CA1 area, starting when an animal was 3 weeks old. These animals showed noticeable deficit of LTP, LTD and performance in the water maze, which reveals an important role that NMDA receptors have in the CA1 area in this type of learning (32).

Now, a different hypothesis is set - if the activation of drastically small amount of NMDA receptors has a bad effect on leaning, what would happen if the number of these receptors is increased? 
At Princeton University, Joe Tsien has recently produced mice in which extra NMDA receptors are formed. These animals demonstrated an increased leaning ability in some tasks. Both genetic and pharmacological studies showed that NMDA receptors played a key role not only in synaptic modification, such as LTP and LTD, but also in learning and memory.

\section{MOLECULAR BASIS OF LONG-TERM MEMORY}

Several systematic models showed that memory could be a result of alterations based on experience in synaptic transmissions (33). In almost all cases, synaptic transmission is modified as a result of changing the number of phosphate groups which are attached to proteins in the synaptic membrane. In the case of sensitization and classical conditioning in Aplysiae, this occurs precisely at certain potassium channels in postsynaptic membrane (34). Concerning LTD and LTP in the human central nervous system, it is highly probable that this occurs at postsynaptic AMPA receptor.

Adding phosphate groups to a protein can cause a change in synaptic effectiveness and form a memory, but only until these phosphate groups are attached to the protein. Phosphorylation as a mechanism of creating longterm memory is problematic for two reasons:

1. Phosphorylation of proteins is not permanent. Over time, the phosphate groups are removed, which causes memory loss.

2. Proteins, like molecules, are not eternal themselves. Most proteins in the brain have a lifespan of two weeks and afterwards they are submitted to a replacement process. It cannot be expected that memories associated with changes in specific protein molecules survive this type of molecular turnover.

However, we have to consider mechanisms which can change what is initially present as a change in synaptic protein phosphorylation into a form that can last the entire life $(34,35)$.

\section{PERSISTENTLY ACTIVATED PROTEIN KINASE}

Phosphorylation of synaptic proteins and memory can last longer if kinases - enzymes that bind phosphate groups to proteins - can be made to stay active ('on') all the time. Normally, the activity of kinases is tightly regulated and they remain active only in the presence of a secondary messenger (35). But what if leaning changes, the kinases so that they do not need a secondary messenger any longer? The relevant synaptic proteins would remain phosphorylated all the time. Recent evidence indicate that some kinases became independent of their secondary messengers. Here, changes that occur will be considered in the example of one protein kinase during LTP in the hippocampus.

\section{CAMKII AND LTP}

Studies have shown that CaMKII stays active ('on') long after $\mathrm{Ca}^{2+}$ ions have gone back to their lower level. CaMKII consists of ten subunits organized in a pattern of rosette (36). Each subunit individually catalyzes protein substrate in response to an increase in Ca-calmodulin. How could CaMKII remain permanently on? The answer to this question includes some knowledge of normal regulation of this protein. Each subunit is built in the shape of a pocket knife, with two parts connected by a hinge. One part, a catalytic region, performs the reaction of phosphorylation. The other part is regulatory $(36,37)$. Normally, in the absence of the appropriate secondary messenger, the knife is closed and the catalytic region is covert by the regulatory region. This keeps the enzyme in the so called "off" state. The normal action the secondary messenger (Ca-calmodulin) is to keep the knife open but only as long as the secondary messenger is present. When the secondary messenger is removed, the molecule usually shuts and the kinase is back to its 'off' state (38). However, it seems that the knife does not close entirely in the alpha subunit of the CaMKII molecule after LTP. The exposed catalytic region continues to phosphorilate substrates of CaMKII .

How does the hinge of the protein molecule remain open? The answer lies in the fact that CaMKII is autophosphorylating protein kinase, each subunit within the CaMKII molecule can be phosphorylated by a neighboring subunit. The result of this phosphorylation is that the hinge stays open. If the initial activation of CaMKII by Ca-calmodulin is strong enough, autophosphorylation will occur before dephosphorylation and the molecule will stay on $(38,39)$. The persistent activity of the CaMKII molecule can contribute to the constant excited state of the synapse, for instance, by keeping AMPA receptors phosphorylated. The general idea that the auto-phosphorylating kinase can store information at the synapse, originally proposed by John Lisman at Brandeis University, is called molecular 'switch' hypothesis.

\section{PROTEIN SYNTHESIS}

The persistently active kinase probably contributes to survival of the synaptic modification, but it can obviously last for a certain period of time (minutes to hours). After that, the requirement for long-term memory lies in the synthesis of a new protein (39). This protein would be used in making new synapses. 


\section{PROTEIN SYNTHESIS AND MEMORY CONSOLIDATION}

The possible role in the synthesis of a new protein in the context of the forming memory has been intensively investigated since the introduction of drugs in 1960 which selectively inhibit dependency of the protein on RNA messenger (mRNA). Protein synthesis inhibitors can be injected directly in the brains of animals that are trained to perform certain tasks in order to track changes (possible deficits) in learning and memory. These studies reveal that if protein synthesis is inhibited during the training, these animals learn normally, but a few days later they show poor results. A deficit in long-term memory is also frequently observed in situations when the inhibitor is injected shortly after the training $(39,40)$. The memory becomes increasingly resistant to the inhibition of the protein synthesis, if the interval between the training and the inhibitor injection increases. These studies indicate a need for new protein synthesis during the period of socalled memory consolidation, when short-term memories are converted into long-term memories. How can we interpret these findings? From what we have learnt thus far, memory formation initially depends on the rapid modification of the existing synaptic proteins. These modifications, probably with the help of persistently active kinases, work against factors which could jeopardize memory storing (such as molecular turnover). The battle can be considered lost if a new protein does not arrive to the location of the modified synapse and change the modification in the synapse for good (40).

\section{CYCLIC AMP RESPONSE ELEMENT BINGING PROTEIN AND MEMORIES}

What regulates the protein synthesis which is crucial for memory consolidation? The first step in protein synthesis is the generation of an mRNA transcript of a gene (41). This process of gene expression is regulated by transcription factors in the nucleus. One of the transcription factors is cAMP response element binding protein (CREB). CREB is a protein that binds specific parts of DNA molecule, called cAMP response elements (CREs) and regulates the expression of neighboring genes $(41,42)$. There are two forms of CREB: CREB-2 inhibits gene expression when attached to CRE; CREB-1 activates transcription, but only when it is phosphorylated by protein kinase A. In initial studies published in 1994, Tim Tully and Jerry Yin at Cold Spring Harbor Laboratory demonstrated that CREB regulated gene expression in situations that require memory consolidation in experiments on the fruit fly - Drosophila melanogaster (18).

In their first series, they bred the fly that would make extra copies of its CREB-2 version (called dCREBb) while the animal was heated (which is a miracle of genetic engineering in fruit flies which is not possible in experiments on mammals). This manipulation stopped expression of all genes that was previously regulated by CREs and blocked memory consolidation for simple associative memory tasks (42). Although the CREB regulation of gene expression is critical for memory consolidation in fruit flies, even more interesting is what is found when flies are generated which can produce extra copies of CREB-1 (called dCREBa). In this case, tasks what would more repetitions in a normal fruit fly now can be learned after a single training. A perfect memory is set in these mutant flies. And these results are not specific only for the fruit fly; it has been proved that CREB regulated consolidation of sensitization in Aplysiae, as well as long-term excitation and spatial memory in mice. As it is known, not all experiences are remembered equally. Some, especially those with strong emotional content, are permanently carved into our memories (43). Others can stay with us for a short time and then fade away. The gene expression modulation by CREB offers a molecular mechanism that could control the strength of a memory.

\section{STRUCTURAL PLASTICITY AND MEMORY}

Long-term memory is associated with forming new synapses, while forgetting is associated with losing them (44). The question is whether there are similar structural changes in the nervous system of mammals after learning? This problem is difficult to solve because of the complexity of the brain of mammals and the distributive nature of memory. Only one approach has been made so far in order to compare brain structures of animals with plenty of opportunity to learn with those of animals with little chance to learn $(44,45)$. Putting a laboratory rat into a complex environment filled with toys and "co-players" (other rats) has resulted in $25 \%$ increase in the number of synapses per neuron in the region of the occipital lobe. It is not necessary to confirm an increased number of synapses as a structural change after learning. For instance, long-term habituation in Aplysiae is associated with a decrease (by 1/3) in the number of synapses per sensory neuron (46). Recent research has also shown that a stimulation that causes long-term depression in the cerebellar cortex reduces the number of parallel synapses with parallel fibers of Purkinje cells.

There are limits to structural plasticity in the adult brain. Large changes in creating neural circuitry of the brain are generally limited to a critical period of early age. Growth and retraction of many axons in the adult central nervous system are limited to no more than several tens of micrometers (47). But now, it is completely clear that the end of the critical growth period does not confirm with certainty the end of changes in the terminal parts of axons or the effectiveness of their synapses $(47,48)$. 


\section{CONCLUSION}

Learning and memory are correlated with the observed changes in synapses. Disregarding the species, location of the brain matter and the memory type, many mechanisms appear to be universal. Events are primarily represented in changes in the electrical activity of the brain, followed by a process that occurs through a secondary messenger, and finally it is shown as modifications of the existing synaptic proteins. These temporary changes are turned into the permanent and long-term memory type by changing the structure of the synapse. In other cases, learning assumes many equal mechanisms which are used to strengthen connections in the brain during development. A universal phenomenon in this entire story is the involvement of $\mathrm{Ca}^{2+}$ ions. Obviously, what $\mathrm{Ca}^{2+}$ does for an organism is much more than building strong bones and teeth. Not only it is crucial in secretion of neurotransmitters and muscle contraction, but it is involved in almost all forms of synaptic plasticity. Since it is a so-called charge carrying ion and a suitable substance in the role of a secondary messenger, $\mathrm{Ca} 2+$ possesses a unique ability to directly bind electrical activity with long-term changes in the brain. It appears that fundamental studies in the field of neuroscience lead us from ions to intelligence. From $\mathrm{Ca} 2+$ ions to cognition.

\section{ABBREVIATIONS:}

AMPA - $\alpha$-amino-3-hydroxy-5-methyl-4-isoxazolepropionic acid,

CA - Cornu Ammonis,

CaMKII - calcium/calmodulin-dependent protein kinase II, cAMP - cyclic adenosine monophosphate,

CREB - cAMP response element binding protein,

LTD - long-term depression,

LTP - long-term potentiation,

mRNA - messenger RNA,

NMDA - N-Methyl-D-aspartate,

PKC - protein kinase $\mathrm{C}$.

\section{REFERENCES}

1. Khrennikov A. Probabilistic pathway representation of cognitive information Journal of Theoretical Biology 2004; 231: 597-613.

2. Rolls E, Treves A. Neural Networks and Brain Function. Science 1998; p418.

3. Rosenblatt F. The perceptron: A probabilistic model for information storage and organization in the brain. Psychological Review 1998; 65: 386-408.
4. Leon NC. Memories and memory: A Physicist's approach to the brain. International Journal of Modern Physics 2000; 15: 4069-82.

5. Obermeyer Z, Emanuel EJ. Predicting the Future Big Data, Machine Learning, and Clinical Medicine, New England Journal of Medicine 2016; 375: 1216-9.

6. Schultz W. Predictive reward signal of dopamine neurons. Journal of Neurophysiology 1998; 80: 1-27.

7. Eshel N, Tian J, Uchida N. Opening the black box: Dopamine, predictions, and learning, Trends in Cognitive Sciences 2013; 17: 430-1.

8. Huttegger S, Zollman K. Signaling games: Dynamics of evolution and learning. Journal of Lecture notes in Computer Science 2011, 6207: 160-76.

9. Bootman MD. Calcium signaling. Cold Spring Harb Perspect Biol 2012; 4: 170-1.

10. Ching TH, Martin KC. Synapse-to-nucleus signaling. Curr Opin Neurobiol 2011; 21: 345-52.

11. Dani A, Huang B, Bergan J, Dulac C, Zhuang X. Superresolution imaging of chemical synapses in the brain. Neuron 2010; 68: 843-56.

12. Furukawa H, Singh SK, Mancusso R, Gouaux E. Subunit arrangement and function in NMDA receptors. Nature 2005; 438: 185-92.

13. Taylor, EW et al. O-GlcNAcylation of AMPA Receptor GluA2 Is Associated with a Novel Form of Long-Term Depression at Hippocampal Synapses. J Neurosci 2014; 34: 10-21.

14. Huganir RL, Nicoll RA. AMPARs and synaptic plasticity: the last 25 years. Neuron 2013; 80: 704-17.

15. Lisman J, Schulman H, Cline H. The molecular basis of CaMKII function in synaptic and behavioural memory. Nat Rev Neurosci 2002; 3: 175-90.

16. Benito E, Barco A. CREB's control of intrinsic and synaptic plasticity: implications for CREB-dependent memory models. Trends Neurosci 2010; 33: 230-40.

17. Nader K. A single standard for memory: the case for reconsolidation. Cold Spring Harb. Perspect. Biol. 2007; 1: 2-16.

18. Aso Y. Mushroom body output neurons encode valence and guide memory-based action selection in Drosophila. eLife 2014; 3: 04580.

19. Liu C. A subset of dopamine neurons signals reward for odour memory in Drosophila. Nature 2012; 488: 512-6.

20. Steinberg E. E. A causal link between prediction errors, dopamine neurons and learning. Nat. Neurosci 2013; 16: 966-73.

21. Chang C, Y. Brief. Optogenetic inhibition of dopamine neurons mimics endogenous negative reward prediction errors. Nat. Neurosci 2013; 19: 111-6. 
22. Ahmad M. Postsynaptic complexin controls AMPA receptor exocytosis during LTP. Neuron 2012; 73: 260-7.

23. Kronschläger MT. Gliogenic LTP spreads widely in nociceptive pathways. Science 2016; 354: 1144-8.

24. Briz, V. A novel form of synaptic plasticity in field CA3 of hippocampus requires GPER1 activation and BDNF release. J. Cell Biol 2015; 210: 1225-37.

25. Kesner RP, Rolls ET. A computational theory of hippocampal function, and tests of the theory: new developments. Neurosci. Biobehav. Rev. 2015; 48: 92-147.

26. Evstratova A, Toth K. Information processing and synaptic plasticity at hippocampal mossy fiber terminals. Front. Cell. Neurosci 2014; 8:28.

27. Isaacson JS, Scanziani M. How inhibition shapes cortical activity. Neuron 2011; 72: 231-43.

28. Cherubini E, Miles $\mathrm{R}$. The CA3 region of the hippocampus: how is it? What is it for? How does it do it? Front. Cell. Neurosci. 2015; 9:19.

29. Münster-Wandowski A, Gómez-Lira G, Gutiérrez R. Mixed neurotransmission in the hippocampal mossy fibers. Front. Cell. Neurosci 2013; 7: 210 .

30. Vyleta NP, Jonas P. Loose coupling between Ca2+ channels and release sensors at a plastic hippocampal synapse. Science 2014; 343: 665-70.

31. Chamberland S, Evstratova A, Toth K. Interplay between synchronization of multivesicular release and recruitment of additional release sites support shortterm facilitation at hippocampal mossy fiber to CA3 pyramidal cells synapses. J. Neurosci 2014; 34: 11032-47.

32. Carta M. Membrane lipids tune synaptic transmission by direct modulation of presynaptic potassium channels. Neuron 2014; 81: 787-99.

33. Mishra RK, Kim S, Guzman SJ et al. Symmetric spike timing-dependent plasticity at CA3-CA3 synapses optimizes storage and recall in autoassociative networks. Nat. Commun 2016; 7: 115-52 .

34. Bazelot M, Teleñczuk MT, Miles R. Single CA3 pyramidal cells trigger sharp waves in vitroby exciting interneurones. J. Physiol. (Lond.) 2016; 594: 2565-77.
35. Guzman, SJ, Schlögl A, Frotscher M. Synaptic mechanisms of pattern completion in the hippocampal CA3 network. Science 2016; 353: 1117-23 .

36. Denny CA. Hippocampal memory traces are differentially modulated by experience, time, and adult neurogenesis. Neuron 2014; 83: 189-201.

37. Hashikawa K. Blockade of stimulus convergence in amygdala neurons disrupts taste associative learning. J. Neurosci.2013; 33: 4958-63.

38. Lee D. Hippocampal place fields emerge upon singlecell manipulation of excitability during behavior. Science 2012; 337: 849-53.

39. Redondo RL, Morris RG. Making memories last: the synaptic tagging and capture hypothesis. Nature Rev. Neurosci 2011; 12: 17-30.

40. Johansen JP, Cain CK, Ostroff LE et al. Molecular mechanisms of fear learning and memory. Cell 2011; 147: $509-24$.

41. Kandel ER. The molecular biology of memory storage: A dialogue between genes and synapses. Science 2001; 294: 1030-8.

42. Keleman K, Kruttner S, Alenius M Et al. Function of the Drosophila CPEB protein Orb2 in long-term courtship memory. Nat. Neurosci 2007; 10: 1587-93.

43. Luscher C, Malenka RC. NMDA receptor-dependent long-term potentiation and long-term depression (LTP/ LTD). Cold Spring Harb Perspect Biol 2012; 10: 571.

44. Watkins JC, Jane DE. The glutamate story. Brit J. Pharmacol 2006. 147: 100-8.

45. Xu T, Yu X, Perlik AJ et al. Rapid formation and selective stabilization of synapses for enduring motor memories. Nature 2009; 462: 915-9.

46. Theis M, Si K, Kandel E. Two previously undescribed members of the mouse CPEB family of genes and their inducible expression in the principle cell layers of the hippocampus. Proc Natl Acad Sci 2003; 100: 9602-7.

47. Zakharenko SS, Zablow L, Siegelbaum SA. Visualization of changes in presynaptic function during long-term synaptic plasticity. Nat Neurosci 2001; 4: 711-7.

48. Won J, Silva AJ. Molecular and cellular mechanisms of memory allocation in neuronetworks. Neurobiol Learn Mem 2008; 89: 285-92. 